\title{
Tūhonotanga-A Māori Perspective of Healing and Well-Being through Ongoing and Regained Connection to Self, Culture, Kin, Land and Sky
}

\author{
Donny Riki Tuakiritetangata ${ }^{1}$ and Alicia Ibarra-Lemay ${ }^{2, *}$ \\ 1 Independent Researcher, Levin Horowhenua, 5510 Aotearoa, New Zealand; donnyr@hotmail.co.nz \\ 2 Department of First Peoples Studies, School of Community and Public Affairs, Concordia University, \\ 1455 Boulevard de Maisonneuve O., Montréal, QC H3G 1M8, Canada \\ * Correspondence: aibarralemay@gmail.com
}

check for updates

Citation: Riki Tuakiritetangata, Donny, and Alicia Ibarra-Lemay. 2021. Tūhonotanga-A Māori Perspective of Healing and Well-Being through Ongoing and Regained Connection to Self, Culture, Kin, Land and Sky. Genealogy 5: 55. https: / / doi.org/10.3390/ genealogy5020055

Received: 3 March 2021

Accepted: 26 May 2021

Published: 4 June 2021

Publisher's Note: MDPI stays neutral with regard to jurisdictional claims in published maps and institutional affiliations.

Copyright: (C) 2021 by the authors. Licensee MDPI, Basel, Switzerland. This article is an open access article distributed under the terms and conditions of the Creative Commons Attribution (CC BY) license (https:// creativecommons.org/licenses/by/ $4.0 /)$.

\begin{abstract}
Tūhonotanga relates to one's physical and spiritual embeddedness to the surrounding world, including to culture, to kin, and to Father Sky and Mother Earth. Kanien'kehá:ka researcher Alicia Ibarra-Lemay from the community of Kahnawà:ke, interviewed Māori psychotherapist Donny Riki from Aotearoa, to explore her practice of healing in relation to her own connections to the Ngāpuhi and the Ngāti Paoa. As granddaughter to Ina Tepapatahi, Patara Te Tuhi, Puahaere, and Haora Tipakoinaki, Donny carries the responsibility for healing in the sense of helping her people find their way back home after 186 years of colonial violence and rule in her homeland of Aotearoa. This chapter discusses the way she works with tāngata whaiora (Māori people, seekers of wellness) and how the process of healing is conceptualized in her Mãori worldview.
\end{abstract}

Keywords: Māori; Tūhonotanga; Indigenous; healing

\section{Introduction \\ Beginning with A Mihi:

$N \bar{a}$ te kukune te pupuke
$N \bar{a}$ te pupuke te hihiri
$N \bar{a}$ te hihiri te mahara
Nā te mahara te hinengaro
Nā te hinengaro te manaāko
Ka hua te wānanga

From the conception the increase From the increase the energy From the energy the remembrance From the remembrance the mindfulness From the mindfulness the longing From the longing the fruitful learning begins
This passage is an excerpt from the traditional Māori whakapapa of creation, a story brought to Aotearoa by its First People, the Māori. This is the story of the birth of the universe and all unknown, the parting of the earth and sky, the introduction of darkness and light, and the world of humankind. In this story, the material world and the spiritual world are one (Henare 2001). They evolve together, and they produce not only the world we see around us but also the world within us, the world of our innermost thoughts and feelings, symbols and images, and dreams and fears (Morice 2003).

In exploring Māori psychotherapist Donny Riki's approach to healing and therapeutic work with the Māori people in Aotearoa New Zealand, readers are invited into a world of Indigenous knowledge and cultural systems of 'relating'. This article places Donny Riki's work into the broader Māori worldview and cosmology, laying out the meaning and significance of important healing interventions, practices, and processes. Herein, concepts such as mana, mauri, and tapu will be presented and explored.

Donny's self-location includes a presentation of her whakapapa (bloodlines), which is indicative of the interdependent relationships to all forms of life (Pere 1991). She formally introduces herself appropriately in this way: 
I te taha o tōku matua ...

Ko Whiria tōku maunga tapu

Ko Hokianga a Kupe tōku moana

Ko Ngātokimatawhāōrua tōku waka tipua

Ko Opononi tōku tūrangawaewae

Ko Ngāpuhi tōku iwi matua

Ko Ina Te Papatahi rāua ko Patara

Te Tuhi ōku tupuna

Ko Maurice Riki toku matua

I haere ia ki te ao wairua hei 64

I te taha ō tōku whāea ...

Ko Kohukohunui te maunga tapu

Ko Ti Kapa o Hauraki te awa

Ko Tainui te waka

Ko Ngāti Paoa tōku iwi whāēa

Ko Haora Tipa Koinaki rāua ko.

Puahaere ōku tūpuna

Ko Dianne Tamihana toku whāea

I haere ia ki te ao wairua hei 64.

Ko Donny Riki taku ingoa

Ko Tuakiritetangata toku ingoa tūturu.

He wahine irapümau ahau

Ko Viv Roberts taku whāiāīpo

He Pākehā ia

Nō Wīwōi, Tākei me Hūrai āna tūpna

E noho ana māua kei Taitoko a Aotearoa Tokorima ngā tamariki waenganui

Tokorua ngā mokopuna ataāhua

He kuri nui hāututu hoki

No reira, tēnā koutou katoa,

Tīhei mauri ora!
On my father's side...

Whiria is my spiritual mountain

Hokianga is my sacred ocean

Ngātokimatawhāōrua is my ancestral ca-

noe

Opononi is my place of infinite belonging

where I will (one day) join my ancestors in spirit

My father's tribal people are Ngāpuhi

My ancestors are Ina Te Papatahi and

Patara Te Tuhi

My father is Maurice Pairama Riki

He passed into the spirit world at 64

years young

On my mother's side...

Kohukohunui is our spiritual mountain

Hauraki is our sacred ocean

Tainui is our ancestral canoe

My mother's tribal people are Ngāti

Paoa

My ancestors are Haora Tipa Koinaki

and

Puahaere

My mother is Dianne Tamihana

She also passed into the spirit world at

64 years young

My name is Donny Riki

My Indigenous name is

One-who-lives-beneath-the-skin

I am a cis-gendered straight woman

My sweetheart's name is Viv Roberts

He is a white settler

His ancestors are French, Turkish and

Jewish

We live in Levin New Zealand

We have five children between us

Two beautiful grandbabies

And a large mischievous puppy

Therefore I greet you and your an cestors And share the breath of life!

This introduction demonstrates how the natural order of Māori lore flows centripetally inward from the cosmological space through time and into human existence. Barlow (1991) defines whakapapa as "the genealogical descent of all living things from the celestial gods to the present time; whakapapa is the basis for the organisation of knowledge and development of all things" (173). It is through whakapapa (family genealogical tree) that Māori identify who and where they come from, and how this links them to the natural world and creation stories (Edwards 2012), which is central to understanding Māori worldviews.

In Donny's whakapapa shown above, she traces her links from earth, sea, and ancestors through time and into future generations. In doing so, she legitimizes her Indigenous authority and guardianship status of Papatūānuku (Mother Earth), specifically, Whiria mountain and Hokianga harbour (Cloher 2004). Whiria mountain is considered Donny's fundamental ancestor - the primordial foremother, before the creation and evolution of mankind (Pere 1988). This is her centre of belonging, where the Ngāpuhi iwi (tribes' people) established themselves and still reside as one with land and sea. Donny's whenua (afterbirth/placenta) is buried there, alongside the whenua of her mighty ancestors and her children. Her grandchildren's whenua will also be buried there, as well as her great grandchildren when the time comes, and so on. Whiria houses the Ngāpuhi guardian spirits 
and the bodies of her ancestors (Marsden and Henare 1992). The Hokianga harbour has produced an abundance of seafood; and native medicinal plants in the nearby forest provided ample nourishment and revitalization for many generations. It is an eternal obligation for Ngāpuhi-past, present, and future generations-to protect and defend the mana (integrity and dignity), mauri (life force), and tapu (sacredness) of Whiria mountain and the Hokianga harbour (Durie 1988).

Māori do not believe in land possession in terms of ownership or real estate but rather in terms of kaitiakitanga, or guardianship (Marsden and Henare 1992). They are guided by and preserve the intelligence of ancient proverbs, such as:

"Ko au te whenua, ko te whenua ko au; ko au te awa ko te awa ko au"

("I am the land and the land is me; I am the river and the river is me").

Like many other Indigenous people Donny believes that 'we do not own land but rather, the land owns us'. Donny's whakapapa is further bound by human connection to great chiefs and warriors bestowing her mana (dignity) and the responsibility to uphold the spirit of her people.

\section{Māori Healing and the Importance of Maintaining Balance}

Māori descriptions of healing transcend western medical descriptions of physical illness or disease, and go beyond concepts of the individualized 'self.' Such notions deny Māori their collective and inherent sense of cosmological belonging, which is firmly rooted in the creation stories of Papatūānuku (Earth Mother) and Ranginui (Sky Father), their Atua (powerful ancestors of the natural world), and their iwi (tribal connections) (Mead 2003).

Māori healing aims for the restoration of balance between four primary dimensions represented by the whare tapa whā (four walls of a house) model of well-being: the tinana (physical body), wairua (life force and spirit), hinengaro (thoughts and feelings), and whānau (kinship ties) (Durie 1988). All four dimensions are important to keep the 'house' upright and stable. If one dimension is lacking, a person becomes unbalanced and subsequently unwell. For Māori, the wairua (life force and spirit) domain is considered the most essential requirement for well-being. A person lacking spiritual awareness is deemed to be kahupō (spiritually blind) and prone to adversities in all aspects of their life.

Durie (1998) further recognized that holistic wellness includes healthy connections with te taiāō (environment) and te ao hurihuri (social world). Understanding the interconnected kinship ties to forests, lakes, animals, and people affirms identity and belonging. In addition, research highlights the need for Indigenous communities to decolonize their historical narratives with the aim of alleviating inter-generational soulwounding (Duran 2015), through pūrākau (story-telling) and mātauranga (Indigenous wisdom) (Edwards 2012).

In 1907, the colonial crown's 'Tohunga (Māori healer) Suppression Act' prohibited traditional Māori healing rituals and ceremony. Outlawed practices included rongoā (medicinal herbs), mirimiri (body work), romiromi (spiritual realignment), pūrea (cleansing rituals), tā moko (facial tattooing), and ipu whenua (burial of the placenta following childbirth). Māori fiercely resisted the Suppression Act and continued to pass their knowledge on to the next generation (Waitangi Tribunal 1995).

The Tino Rangatiratanga (Māori renaissance) movement peaked during the 1970s when the Waitangi Tribunal was established to contest breaches made by the crown legitimized by Te Tiriti O Waitangi (the Treaty of Waitangi). This social, political, and spiritual movement contested the racial inequalities and inequities prevalent in Aotearoa New Zealand society, made space for these grievances to be challenged, and mobilized the revitalization of te reo Māori (language), tīkanga (culture), and hauora (healing practices).

These practices have since forged their way into mainstream spaces and are now being taught at Indigenous tertiary institutions (Waitangi Tribunal 1995). It is fair to surmise, therefore, that Māori need healing from the genocidal, ethnocidal, and ecocidal harms of colonization. 


\section{Continuing with a Story of Love}

According to traditional Māori creation stories, the origin of the world begins with a love story. From Io Matua Kore (Great Spirit and Creator), emerged Ranginui (Sky Father) and Papatūānuku (Earth Mother). They loved each other passionately and, for eons, lived in a loving embrace basking in the qualities of each other. Ranginui and Papatū̄anuku were blessed with 72 children, all of whom lived in the confined space between them in darkness. Each time their parents moved, a glimpse of light came through but the darkness always returned.

As the children grew, so too did their desire to live in the light and seek an open world. They debated ways to let more light in. Seven of the children argued amongst themselves to find a solution: Tāne Mahuta (Atua of trees and living creatures) suggested their parents be separated; Tümatauenga (Atua of conflict), the fiercest of the children, proposed to kill their parents; Tangaroa (Atua of oceans and sea life) agreed to the separation and wanted to remain close to his mother; Haumietiketike (Atua of fernroot and crops) became afraid and nestled himself into his mother's breast; Rongomātāne (Atua of peace and harmony) wanted peace; Ruaūmoko (Atua of earthquakes) wanted to remain in a world of cramped darkness; and Tāwohirimatea (Atua of wind and weather patterns) opposed the separation and feeling betrayed by his siblings, wanted to stay close to his father.

Many attempts by the children were made to separate sky and earth, who held on to each other tightly. One day Tāne Māhuta, laid down on his back, pressed hard against his mother and pushed his feet up in the air against his father forcing them apart. As light flooded into the world, the children became Atua-powerful ancestors of different realms now known to mankind as nature. Tangaroa lovingly covered his mother with oceans, Tāne Māhuta clothed her with trees and plants and Ruaümoko remains unborn suckling, rumbling and kicking inside her belly. Täwhirimätea remained with his father whom he adorns with cloaks of stars. Still angry with his siblings, he unleashes his fury onto the world with harsh weather patterns-storms, hurricanes, and cyclones.

Tāne Māhuta and 17 of his other siblings together created mankind, moulding the first human being-a woman, from the sacred ochre clay of Kurawaka. As Tāne Māhuta gently pressed against her nose and breathed into her nostrils, the figure sneezed and drew a breath saying "tihei mauri ora!" ("behold, the breath of life!"). She was named Hineahuone (earth-formed maiden) a creation of perfection designated with the 'whare tangata', the sacred gift of 'housing' and bringing new life into the world.

Lee (2009) and Edwards (2012) asserted that pürakau (traditional stories) like these, support making meaning of natural phenomena and the linking of events that are experienced in everyday life. Rain are the tears of Ranginui as he weeps for his love and as the mist rises from the earth, it is Papatūānuku yearning and reaching out to be with him. And it is in this life force, this abundant nature, that everything is linked together. It is through the natural world that the links between man and ancestors are made. Reed (2004) added that, for the Māori, the land is an eternal source of life and spirituality from which they originate and how they connect to everything else.

\section{The Greeting and the Beginning of the Interchange-Symbolism of the Hongi}

Māori healing work begins with hongi, the graceful leaning in together and pressing of noses while inhaling the breath of each other's wairua (spirit and life force). This symbolizes an exchange of energy - a greeting of peace, openness, transparency, and an agreement to be "upright" with one another. It bridges the meeting point of two worldviews, cosmologies, and epistemologies and is an unspoken commitment to bring these views closer together in the interchange (Henare 2001).

This deeply spiritual gesture has two primary meanings: First, this state comprises oneness of thought, desire, purpose, and hope and, as such, is the anticipated intention of the encounter. The physical closeness represents the peaceful connection experienced by Ranginui and Papatūannuku before they were separated. The second meaning of the hongi represents life and immortality, symbolized by the action of Tāne Māhuta breathing life 
into Hineahuone. By this action, the life-force is permanently established, and the spiritual and physical bodies become a single entity. As the heartbeat provides life in a physical sense, the mauri ensures that the life force is established (Barlow 1991). The exchange of breath imbued by the Atua (primordial ancestors) unifies the spiritual presence of the past, present, and future between two people, between two tribes, and/or between two cultures.

\section{Making Relationship}

As is important in all Māori interactions, a proper introduction through self-location is exchanged. This process of engagement, called whakawhanaungatanga (making relationships), is a formal introduction of 'self' through whakapapa, such as the one demonstrated at the beginning of this article. It is important to note that historical inter-tribal transgressions may have occurred between the healer's tribes people and the whaiora's (seeker of wellness). During this encounter, grievances can be acknowledged in honour of what has been lost. By the same token, there are also inter-tribal triumphs, which can be commended and celebrated (Duran and Firehammer 2013). This introductory phase takes time, practice, and patience unfolding over several healing sessions, and space needs to be made to honour these points of connection.

"Tìtiro whakamuri, kōkiri whakamua" (we must first look back to move forward). This proverb highlights the need to acknowledge what lies behind us so that we can learn from our mistakes and move forward with intention. It also speaks to the idea is that if a person does not know where they come from, how can they help someone else get to where they need to go? When Māori meet other Māori, the main question is usually "nō hea koe?" (where are you from?/ which tribe do you belong to?), rather than "what kind of work do you do?", or "where do you currently live?" (Durie 1998).

Whakawhanaungatanga creates a 'bubble' of cultural safety, which is necessary to continue to the next step of healing (Durie 1998). Once this has been established, sessions begin and end with karakia (incantation or blessing). At the beginning, karakia shifts the space from noa (normal) to tapu (spiritually protected). Ancestors are invited to uphold the mana (authority and dignity), mauri (life force), and tapu (sacred seed) of whaiora. It calls to the Atua (primordial ancestors) for ease of mamae (spiritual and physical suffering) and supports whaiora to deepen into their intuition, wisdom, and light, which they may have been disconnected from. At the end of the session, karakia (closing incantation) is used to shift the space back to noa (normal). Ancestors are thanked and asked to take any pain and distress back to the spirit world.

\section{Healing Space}

Donny rents an office in town that is attached to a small-sized medical centre and pharmacy. The space feels upbeat and modern-non-clinical yet professional, spacious yet contained, and multi-culturally influenced yet inherently Māori. The muted coloured walls are embellished with Indigenous art works from Aotearoa, Country, and Turtle Island. A large window together with lamps and candles provides ample lighting. There are also other traditional Māori crafts made from flax or wood, which can be held and stroked or used to entice attentive conversations. The placement of sacred stones sourced from the northland, southland, east coast, and west coast are placed in each corner of the room as pillars of ancestral acknowledgement and strength. A large pounamu (jade stone) sits beside the open window to purify the wairua (spirit) by sending negative energy out of the room and into the spirit world of ancestors. A mini kitchenette in the room provides the added convenience for endless cups of herbal tea.

In between healing sessions, Donny carries out a takutaku (ancient chant) to transition the space from tapu (spiritually protected) to noa (normal). She also washes her hands and face to cleanse her mauri (life force), energy, and spirit. 


\section{Beginning a Healing Session}

Donny usually communicates with whaiora by email or phone to set up an initial appointment. This gives her a sense of their needs, cultural positioning, Māori language fluency, or any social barriers that may hinder their attendance i.e., transport, work hours, or child-care. They are invited to bring along a significant other if they wish, or she will meet them in their home or at their marae (traditional meeting house) if they prefer.

Donny begins with hongi and the whakawhanaungatanga (making relationship) process. She speaks initially in Māori, beginning with a mihi, which is a formal acknowledgement of the cosmos and the forces that bind them together. She then recites her whakapapa, which is followed by a waiata (tribal welcoming song).

The whaiora (and others in attendance) are then invited to introduce themselves by responding in kind. Whilst many Māori know their whakapapa and can speak the language to reciprocate this exchange fully, many do not. Mikaere (2001) emphasizes that while forces of colonization disconnected and displaced Māori from their language, tribal land, familial links, and cultural ties, healing endeavours to restore these connections. These formalities are conducted in a standing position as a token of respect to ancestors and those who have passed on to the spirit world.

\section{Processing Past Violence and Traumatic Experience}

Women possess the whare tangata 'house of mankind'-that is, the reproductive physiology to bring new life into the world. According to pürākau, she is subsequently the link between humans and the primordial ancestors and the cosmos. At the point of conception, mauri (life force) and wairua (spiritual links) are implanted into the embryo, preserving the connection between the growing child, Atua (primordial ancestors), human ancestors, and future generations. Women are also the well spring of tears, bearing the burden of sorrow for the pain and suffering experienced in life (Barlow 1991). Mildon (2017) further adds that women who experience sexualized violence have their mana (dignity), mauri (life force), and tapu (spiritual being) violated, which directly affects her whakapapa from the past and into her future generations.

Her whare tapa wha sustains significant injuries in the following ways:

Taha wairua: Sacred and spiritual lores of womanhood, pride, and authority have been severely desecrated by the violent disconnection from her Atua (primordial ancestors), spiritual beliefs, and ancestors.

Taha whānau: The connection to ancestors and future generations through the womb is broken, often prompting women to question their identity, purpose, and position within their whānau (family) and society.

Taha tinana: Physical harm to the body-particularly the vagina, womb, abdomen, and breasts. Without appropriate spiritual healing, disease is believed to manifest in these targeted areas as somatizations in the form of endometriosis, fibromyalgia, PCOS, fibroids, cystitis, and mouth, or throat ulcers.

Taha hinengaro: Emotional overwhelm and distressing thoughts occur as mana and mauri are compromised.

Healing requires rebalancing the whare tapa wha at all four dimensions of being, with particular attention to spiritual recovery, reconnection, and reconciliation (Durie 1998).

\section{Going into the Healing Experience}

Donny recalls, as a lively youngster, sitting under a tōtara tree with her grandmother one day. Here, her grandmother taught her to see the world behind closed eyes, feel the heartbeat of the earth beneath her, the vibration of the trees, and talk with her ancestors. In this place she experienced a depth of inner calmness, aliveness, and a higher intelligence through her grandmother's pūrākau (creation stories), chants, and lullabies. Accordingly, these gifts are included in nohopuku (mindfulness), which Donny now demonstrates as a 'body scan' in her healing practice as illustrated in the following vignette: 
"Gently closing your eyes, bring your attention to your breath coming into your body, just notice what you notice... letting go of the busyness of your day ... and with each out breath letting go of the weight in your shoulders ... and your neck... just soften the muscles in your face... relax your jaw ... and just notice what you notice. Gently guide your attention to the sounds of nature... let go of making sense of things and just observe your experience as it is ...

Notice what you can hear ... or anything you can smell ... allow memories or thoughts to just be here if they arrive ... allow your senses to heighten ...

Notice the rhythm of your breath gently slow ... allow the weight of your body to fall into the centre of your being ... and now we will invite our Atua to bear witness to your experience..."

In this relaxed state, takutaku (ancient chants) are used to awaken the spiritual heart through which the essence of life and the influence of Atua might be manifested. This particular example is a simple chant, which breathes life into connections with cosmology, the universe, and ancestry:

"Io nui, Io roa, Io te mataoho, Io te matua, Io taketake,

Io wānanga, Io tiketike $i$ te rangi

Ranginui, Papatūānuku

Tāne Māhuta, Tangaroa, Rongomatāne, Haumietiketike

Tumatauenga, Ruamoko, Tāwhirimātea, Whaitiri, Rehua, Whiro

E kore au e ngāro

He kākano he kākano

I ruiruiā mai i Rangiātea

Io Io $\mathrm{Io}^{\prime \prime}$.

Silence is used to intuit, track, and gauge the wairua (spiritual energy) in the room. Donny will pause here to rest a while and make contact with the whaiora making comments that support the whaiora to stay in a deepened relaxed state, like "you're doing really great", "you're breathing nice and deeply now", or "you look really relaxed". She then guides them back up the body, bringing in the presence of Atua at various points of contact.

"Feel the presence of Tāne Māhuta, Atua of trees and living creatures ... and the source of root our connection ... strong and secure ... anchoring your feet to the earth like the tōtara tree...

Feel the connection to Papatūānuku (Earth mother) .... . Feel the wairua (spiritual energy) of her heartbeat beneath you ... stable, permanent, constant ... breathe in her healing energy through the soles of your feet ... give yourself permission to take as much as you need...

Move your attention up your legs and into your thighs noticing how your body makes contact with the couch you are sitting on. Breathe gently into your pelvis ... feel your belly slowly rise and fall ... feel the presence of Tangaroa, Atua of the ocean and source of emotional turmoil ... notice how your internal moana (ocean) is calm and relaxed right now ....

Move your awareness to your chest and notice how it gently rises and falls ... see if you can feel your heart beating ... feel the presence of Rongomātāne, Atua of peace and the realm of love and compassion ... allow this feeling to wash over you ...

Gently moving your awareness up to your shoulders and your throat, feel the presence of Täwhirimātea, Atua of the wind and the realm of expression ... remember moments of how you feel when you speak your truth... 
Slowly bringing your attention into your face and resting on your forehead just between your eyes ... invite the presence of Tänenuiarangi, Atua of the sun and the realm of spiritual intelligence... notice how this energy centre opens up to new possibilities and ways of being ...

Now bring your attention to the very top of your head, feel the warm presence of Ranginui our Sky Father, healer and link to Io (supreme being)... Just notice what you notice in this moment ... and just when you're ready ... feeling relaxed and alert... gently bring yourself back into the room ..."

Variations of nohopuku are used in the sessions that follow to invite spiritual presence and attention, where gentle conversations unfold, depending on what is needed. Donny brews a pot of herbal tea to share and listens intently to stories of pain, unmet sorrow, and suffering.

\section{Healing Narratives, Pūrākau, and 'Lensing'}

During intimate conversations, Donny draws close attention to how whaiora have resisted violence throughout their life by reflecting back their stories in a simple uplifting manner. For example, she might say something like "oh, so even as a child you figured out that when your dog was near you, he (the perpetrator) stayed away because he didn't like the $\operatorname{dog} . .$. and so your whole life, you've always had a dog to feel safe .... I get it-but how did you get to be so clever like that?".

Or in another conversation she says, " ... so you think that shaving your hair makes you somehow less feminine or less attractive ... and less likely to be raped because of it ... and he can't drag you by the hair when he assaults you ... wow, that's brilliant! Who taught you how to create safety like that?" Richardson and Wade (2009) highlight how conversations like these uplift people's dignity once they recognize how they have created safety and resisted violence, which is pertinent for healing in that it highlights the person's agency and activity as well as their reasoning behind it. Exploring the ways that the English language dismantles mana (dignity and integrity) mauri and tapu can help whaiora 'make sense' of experiences cognitively and emotionally. As the whare tapa wha suggests, Māori worldviews are holistic and healing extends beyond the limitations of talk therapies for wellbeing (Mildon 2017). Working with the body physically 'processes' experience, while working within the spiritual realm 'integrates' it. Having family members and/or loved ones included in the healing journey is mostly beneficial, to bridge the spaces between the spirit, physical, and social worlds with significant others.

Donny also works at the unstated fifth dimension of whare tapa wha (the dimension of time), which acknowledges the pervasive layers of colonization. The popular proverb "tītiro whakamua, kōkiri whakamuri" (we must first look back to move forward) refers, in this context, to historical genocide and ongoing oppression. The Inter-generational Trauma Framework is a useful platform for Indigenous communities to make sense of colonization and its ensuing suffering (Smith and Wirihana 2014). The framework requires continually lifting the veil to reveal the brutal reality of colonial violence for what it is. Brave Heart (2003) described these traumas as the "cumulative emotional and psychological wounding over the life span and across generations". Duran and Firehammer (2013) described this as "deep soul wounds, transmitted from one generation to the next".

Donny draws on the ancient wisdom of pūrākau, traditional codified stories of creation, Atua, and ancestors. The story of Hineahuone as shared at the beginning of this article, is one such example as it emphasizes the tapu (sacred) rites and rights of women. The separation of earth and sky, a painful love story, is experienced when families separate. Reconnecting with these stories, re-identifying with the power of these ideas, and applying them into everyday life as is context appropriate, encourages Māori to view their ancestral knowledge as valuable and worth holding onto (Salmond 1985). Richardson (2016) further agreed that pūrākau are the medicine that reinforces a sense of Indigenous belonging and identity as an antidote to cultural erasure. 
Royal (2008) notion of 'ancestor lensing' further explores and filters points of connection to pürākau for practical application. For example, Donny might ask things like "so how do you think (your ancestors) might view this situation? Or, how do you think (he/she/they) might respond to it?", or perhaps even, "what guidance do you think (he/she/they) would give to your great-great-great-grandchild if they were facing the same situation?". These types of enquiry link the past to the future by honouring ancestral bravery, strategy, and survival.

Being curious about previous generations may lead to enquiries, such as "so in what ways did your ancestors resist violence? How do you think our tribes worked together to uphold our rights for Sovereignty? And what kinds of things do you do now, to uphold the mana of your great-great-great-great-grandchildren?" Such conversations illuminate the power, vitality, and competency of Indigenous knowing and belonging. It is much more uplifting to explore the notion of intergenerational resistance to oppression rather than the intergenerational effects, which cast Indigenous people as passive or broken (Richardson and Wade 2009). Another way of acknowledging and reconnecting with these ideas is to access and engage in the rich sources of belonging that are available and reflected in Māori language, art, music, and landscapes as taonga tuku iho (gifts handed down by ancestors) - timeless and epistemological truths (Edwards 2012).

All of these ideas organically flow in the context of the healing sessions, which generally occur over $60 \mathrm{~min}$, once a week. Toward the end of each session, Donny will ask "so what did you notice about yourself today?" or, "what, if anything, did you find most useful?" to invite self-reflection and curiosity.

After several sessions of nohopuku and meaningful conversations, whaiora organically come to a place within themselves of restored energy and enlightenment. At this point, they will share a light meal and sing tribal songs to acknowledge the end of their journey together in the healing context. This process, called poroaki (farewell) is a joyful celebration of new beginnings and rebalances the relationship back to whakanoa (from sacred to normal).

\section{The Experiential Healing Ceremony}

Some whaiora may require romiromi (deep tissue body work) intended to expel harmful spiritual energies that have embedded themselves in the body or to explore illnesses beyond medical explanation or care (NiaNia et al. 2017). This is known as mate Māori (Māori spiritual dis-ease). Donny appreciates that this is a highly specialized area and, in these cases, will refer whaiora to a tohunga (specialist healer).

Whaiora may continue their therapeutic journey with Donny in a traditional healing ceremony that usually takes place on a marae (traditional gathering house), urup $\bar{a}$, (tribal burial ground), or türangawaewae (tribal land of belonging), such as a sacred mountain or stream. The ceremony centres on reconnection and addresses multiple layers of violence whaiora have experienced in this physical lifetime. It also alleviates the soul-wounding (Duran 2015) caused by colonization, across time and across generations. The ritual itself is so powerful and meaningful, it only needs to be carried out once.

Karanga (spiritual call) is an ancient ritual and rite of passage that is practiced by wāhine (Māori women) only. This is because only wāhine (women) possess whare tangata (house of mankind) linking humans to ancestors, Atua, and the cosmos. Karanga is a high wail-like chant, likened to the cry of the wahine (woman) as she gives birth to her child when the baby leaves the womb and enters the world of light. The vibrational frequency of the call is believed to penetrate beyond the confines of the physical world and into the spiritual realm, arousing the spirits of those who have passed on (Barlow 1991; Pihama 2001; Te Awekōtuku 2003). The lyrics are written as a powerful and expressive call for guidance, strength, and support from the Atua and ancestors; the cathartic cry is expelled from the womb, linking the past to the present and the present to the future.

Karanga parallels eurocentric ideas of the primal scream, which psychotherapists describe as "a rageful verbal outpouring of raw emotion" (Firman and Gila 1997). Similarly, Sanskrit teachings may regard this as the activation or unblocking of the seven chakra 
points located in various locations throughout the body (Pond 2003). Preparation of this healing ritual supports wähine (women) to compose lyrics for their karanga. This requires an investigation into ancestral origins and tribal knowledge, and a confident level of fluency of the Māori language (Yates-Smith 1998). Often kaumātua (elders) are consulted to advise or support this process.

When whaiora feel ready and have composed the lyrics to their karanga, Donny accompanies them to an appropriate location of their choice to perform it, with each site, according to Mildon (2017), having its own unique advantages:

Marae: The traditional gathering house is abundant in carvings, art, and symbols that depict the tribal narratives of that particular iwi (tribes people). This is a useful place to begin tangible reconnections to cultural identity and belonging.

Urupā: Tribal burial grounds are a powerful space to karanga in the physical presence of ancestors, particularly if the abuser has passed on and is buried there. The karanga may be a call for support from those who have passed on, or an angstfilled wail of pain and anger-either way, the spiritual and physical suffering is laid down and left there where it belongs.

Awa: The mauri (life force) of the awa (water) flowing freely in a stream offer spiritual and physical cleansing. The tears of Ranginui that flow down the mountains and fill lakes and streams offer regeneration, renewal, and revitalization. Wading into the cool water while performing karanga signifies new beginnings and a sense of wholeness. Maunga: The sacred mountain is likened to the nipple of Papatūannuku as it provides iwi (tribes people) with nourishment, safety, and permanence. The top of the mountain is the closest point of contact to Ranginui and the highest perspective from which to view the nearby marae (traditional meeting house), the awa (sacred water body), and the $u r u p \bar{a}$ (tribal burial ground). A Karanga from this position is a powerful cry of connection, triumph, and victory.

When Donny works with tāne (men) seeking reconnection and recovery from sexualized violence, her healing journey with them is similar to the path shared with women. However, men do not perform karanga, so she will support them to compose and perform a haka (ceremonial war dance). Whether whaiora are wähine (women) who learn to karanga, or tāne (men) who learn to haka, these deeply healing processes are transformative for those brave enough to journey into it. It is also important to note that the experiential ceremony cannot occur until the healing narrative journey has been completed. This is to ensure that spiritual safety has been well established, tried, and tested within the therapeutic safety of the healing room.

\section{Integrating and Reflecting on the Experience}

It is not uncommon for whaiora to press pause on their healing journey, especially when they have children, elders, and jobs to also tend to. Funding parameters and limitations may also interrupt their journey from time to time, as traditional healing practices still struggle for legitimacy in mainstream funding spaces. In saying that, whaiora usually tend to re-engage after a while when the timing is more suitable for them. In terms of healing, the initial 'round' is usually the most significant, where whaiora have travelled the farthest distance within the shortest amount of time. The whakawhanaungatanga process of engagement secures a lifelong relationship, both in a therapeutic context and within other tribal spaces.

On completion of the journey, whaiora often report feeling a new sense of aliveness and vitality. They tend to have either fully restored or exited their intimate partner relationship. Their familial relationships seem more cohesive. Most whaiora return to study in the pursuit of Indigenous knowledge or professional training. Many return to work. Physical illnesses often dissipate. What is most noticeable overall, however, is the reconnection to Māori worldviews and reclamation of Māori identity. Healing can be a lifelong process for many. Using Indigenous methods is often the most effective way to heal Indigenous suffering. Māori healing is currently relishing in the space it has been denied for almost 200 years. 
Inspired by global Indigenous research, Māori are engaging more assertively now than ever before by protecting and upholding what is traditionally theirs. Perseverance and endurance is necessary for change, as reflected in the following whakatauki (proverb):

"Whāia te iti kahurangi, ki te tūohu koe me he maunga teitei"-

"Seek the treasures you value most dearly, if you bow your head, let it be to a lofty mountain".

Author Contributions: Conceptualization, D.R.T.; resources, D.R.T.; writing—original draft preparation, D.R.T.; writing - review and editing, D.R.T. and A.I.-L. All authors have read and agreed to the published version of the manuscript.

Funding: This research was funded by the Social Science and Humanities Research Council (SSHRC) Connection Grant (agency reference number 611-2020-0074; IUD: 260015) and Concordia University (S02315).

Institutional Review Board Statement: The study was conducted according to the guidelines of the Tri-Council Policy Statement: Ethical Conduct for Research Involving Humans under the Office of Research, Research Ethics Unit in the Official Policies of Concordia University, including the Policy for the Ethical Review of Research Involving Human Participants, VPRGS-3. This research received the Certification of Ethical Acceptability for Research Involving Human Subjects (approved 3 November 2020; certification number 30013765).

Informed Consent Statement: Informed consent was obtained from all subjects involved in the study.

Data Availability Statement: Not applicable.

Conflicts of Interest: The authors declare no conflict of interest. The funders had no role in the design of the study; in the collection, analyses, or interpretation of data; in the writing of the manuscript, or in the decision to publish the results.

\section{References}

Barlow, Cleve. 1991. Tīkanga Whakaāro: Key Concepts in Māori Culture. Victoria: Oxford University Press.

Cloher, Dorothy. 2004. A perspective on early Māori relationships with their land. In Spiritualities from Aotearoa/New Zealand. Edited by Helen Bergin and Susan Smith. Auckland: Accent Publishers.

Duran, Eduardo, and Judith Firehammer. 2013. Story Sciencing and Analyzing the Silent Narrative between Worlds: Counselling Research from an Indigenous Perspective. New York: Springer.

Duran, Eduardo. 2015. Healing the soul wound. Synergies in Healing Journal, April 3. Available online: http:/ / www.synergies-journal. com/synergies/2015/4/2/eduardo-duran-overcoming-historical-trauma (accessed on 26 February 2021).

Durie, Mason. 1988. Māori cultural identity and its implications for mental health services. International Journal of Mental Health 26: 22-35. [CrossRef]

Durie, Mason. 1998. Whaiora: Māori Health Development. Green Lane: Oxford University Press.

Edwards, Shane. 2012. Nā te mātauranga Māori, ka ora tonu te ao. In Conversations on mātauranga Māori. Indigenous Business Magazine: Koha 2011. Auckland: Auckland University of Technology, pp. 37-58.

Firman, John, and Ann Gila. 1997. The Primal Wound: A Transpersonal View of Trauma, Addiction and Growth. New York: New York Press.

Heart, Maria Yellow Horse Brave. 2003. The historical trauma response among natives and its relationship with substance abuse: A Lakota illustration. Journal of Psychoactive Drugs 35: 7-13. [CrossRef] [PubMed]

Henare, Manuka. 2001. Tapu, Manu, Māori, Hau, Wairua: A Māori philosophy of vitalism and cosmos. In Indigenous Traditions and Ecology: The Interbeing of Cosmology and Community. Cambridge: Harvard University Press, pp. 198-221.

Lee, Jenny. 2009. Decolonising Māori narratives: Pārākau as a method. MAI Review. 2. Available online: http://review.mai.ac.nz/ index.php/MR/article/viewFile/242/268 (accessed on 26 February 2021).

Marsden, Māori, and Te A. Henare. 1992. Kaitiakitanga: A Definitive Introduction to the Holistic World View of the Māori. Wellington: Ministry for the Environment.

Mead, Hirini M. 2003. Tīkanga Māori: Living by Māori Values. Wellington: Huia Publishers.

Mikaere, Ani. 2001. Patriarchy as the ultimate divide and rule tactic: The assault on tīkanga māori by pākehā law. Paper presented at the Mai te Ata Hapara Conference on the Principles and Relevance of Tīkanga Māori, Te Whare Wānanga Ō Raukawa, Otaki, Aotearoa, New Zealand, August 11-13.

Mildon, Charlotte. 2017. The Essentialism of the Tohuna. Master's thesis, Te Whare Wānanga o Awanuiārangi, Aotearoa, New Zealand. 
Morice, Margaret. 2003. Towards a Māori Psychotherapy: The Therapeutic Relationship and Māori Concepts of Relationship: A Systematic Review with Case Illustrations. Master's thesis, Auckland University of Technology, Auckland, Aotearoa, New Zealand.

NiaNia, Wiremu, Allister Bush, and David Epston. 2017. Collaborative and Indigenous Mental Health therapy: Tātaihono—Stories of Māori Healing and Psychiatry. New York: Routledge.

Pere, Rangimarie R. 1988. Te wheke; Whaia te māramatanga me te aroha. In Women in Education in Aotearoa. Wellington: Allen and Unwin.

Pere, Rangimarie R. 1991. Te Wheke; A Celebration of Infinite Wisdom. Whakatāne: Ao Ako Global Learning New Zealand Ltd.

Pihama, Leonie E. 2001. Tīhei Mauri Ora-Honouring Our Voices; Mana Wahine as a Kaupapa Māori Theoretical Framework. Unpublished Ph.D. thesis, University of Auckland, Auckland, New Zealand.

Pond, David. 2003. Chakras for Beginners: A Guide to Balancing Your Chakra Energies. Minnesota: Llewellyn Publications.

Reed, Alexander W. 2004. Book of Maori Mythology. Wellington: Reed Publishing.

Richardson, Catherine, and Allan Wade. 2009. Taking resistance seriously: A response based approach to social work in cases of violence against Indigenous women. In Walking This Path Together: Anti-Racist and Anti-Oppressive Child Welfare Practice. Winnipeg: Fernwood.

Richardson, Catherine. 2016. Belonging Mètis. Charlton: Charlton Publishing.

Royal, Te Ahukaramu Charles. 2008. Te ngākau. Wellington: Mauri-ora-ki-te-ao/Living Universe Ltd.

Salmond, Anne. 1985. Māori epistemologies. In Reason and Morality. Edited by Joanna Overing. London: Travistock Publications.

Smith, Cherryl, and Rebecca Wirihana. 2014. Historical trauma, healing and well-being in Māori communities. MAI Journal 3: 197-210.

Te Awekōtuku, Ngahuia. 2003. Ruahine: Mythic Women. Wellington: Huia Publishers.

Waitangi Tribunal. 1995. Te Whanganui-a-Orotu Report. Available online: http:/ / www.waitangi-tribunal.govt.nz (accessed on 26 February 2021).

Yates-Smith, Aroha. 1998. Hine! E Hine! Rediscovering the Feminine in Māori Spirituality. Ph.D. thesis, University of Waikato, Hamilton, New Zealand. 